\title{
The Effects of Various Modes of Online Learning on Learning Results
}

\author{
Muhammad Rusli \\ Faculty of Informatics and Computer \\ STIKOM Bali Institute of Technology and Business \\ Denpasar, Indonesia
}

\begin{abstract}
The demand for online learning particularly in a college is necessity to be developed and implemented as an alternative method of delivery learning materials in this millennial era. Nowadays, the developments are strongly supported by the advancement of Information Technology and Communication (ICT) and Multimedia Technology. Nevertheless, during the development or engineering process of the online learning, the principles of interactive, creative and effective learning deserve attention. The challenge now is the suitable mode of online learning decided to be developed and applied so that the learning process is conducted effectively. There are few things to be considered in the development of the learning, such as: how large the percentages of the number of online meetings are in comparison to face-to-face meetings and how the content type. This study aims to investigate the effects of various modes of online learning to the learning result. There are some teaching methods or modes namely face-to-face, blended, web, and online learning. This experiment is conducted to implement all the same learning materials and is available online for the four online learning modes. The research subject observed is the students of ITB STIKOM BALI who attend the Multimedia Learning course in odd semester 2019/2020. There are four classes with 108 students and each class is given a different mode of online learning. The method of analysis of this study is the statistical analysis, ANCOVA Univariate, on which 1 factor with 4 treatments. The result of this study revealed that there is equality of the students' learning results toward the four modes of online learning. Therefore, the development of online learning for conceptual types of teaching materials or the achievement of student learning at the level of understanding is recommended.
\end{abstract}

Keywords-Online learning; web learning; blended learning; face to face learning; interactive multimedia learning; learning results

\section{INTRODUCTION}

Online learning is learning delivered through web-based or cloud-based technology [1]. There are three kinds of online learning modalities, namely: web-based (web facilitated modality, covers $1-29 \%$ of online learning and the rest of faceto-face or in-class learning), mixed (blended/hybrid modality, covers $30-79 \%$ of online learning and the rest of face-to-face or in-class learning), and online (online modality, including $80-100 \%$ online learning and the rest of face-to-face or inclass learning) [2]. The growth of this online learning has taken place in such a rapid and widespread in the last decade, especially when viewed from the aspect of the number of admissions participants or students [3]. Factors affecting the growth such as: the reputation of the institution (accreditation status), relationships between participants, the price/tuition fees, reduced/absence of face-to-face classes, the presence of credit transfer policies, and an efficient registration process.

The results [4] prove that interactive activities on online learning can increase student results compared with a face-toface or conventional learning. However, the research results from [5], [6] indicates that online learning format compared to conventional learning results the equal output. Furthermore, in the context of online learning in blended format, when compared to studies in class or conventional learning, [7] stated that the blended learning strategy is more effective than conventional learning, while [8] provides different results, i.e. online learning in blended format shows the performance of students learning results that are equality when compared to classroom/face-to-face/conventional learning [8]. It appears that there is a difference/similarity or inconsistency of research results from some previous researchers about the effectiveness of learning strategies in online, blended, and face-to-face formats. These conditions can occur because of several factors such as: content types (facts/concepts/procedures/principles), delivery type, learning objectives, and learning strategy [9]. In addition, [10] stated that, in relation to learning via multimedia, effectiveness of learning depends also on the availability of leaner control, interactive learning facilities, and content visualization types (static/animated).

The problem emerged is related to the online learning, as mentioned earlier, [2] the three modes namely blended, web, online. There are two research questions: the first, which mode is more effectively reviewed from the access aspects of the student's learning results? And the second, how far is the effectiveness of the three modes of online learning compared to the mode of face-to-face learning in the class room or conventional?

Conclusion and recommendations of the research will certainly be very beneficial in the implementation of Distance Education (Pendidikan Jarak Jauh atau PJJ), which in this case the regulation has been issued by the Government of Indonesia through the Ministry of Research and Technology number 51 year 2018, about the organization of Distance Education (PJJ/Online learning) in higher education. Of course, the expected recommendation of the results is, at least, the equality effectiveness of the 3rd modes of online learning when compared with the mode of face-to-face learning in the class room or conventional learning to the achievement of student learning results. 
ITB STIKOM BALI, as a higher education in Information and Communication Technology (ICT), certainly has been moved to participate in implementing online learning. It has been demonstrated in the development of an interactive online learning (or blended learning) at ITB STIKOM BALI which has been pioneered, studied, engineered and implemented in the academic year 2017/2018 and 2018/2019 (working with third parties, as a pilot project) for the 2 courses of conceptual content type in the first year for new students. In addition, the ITB STIKOM BALI through internal research fund, starting in 2018-2019, independently has also developed online learning for 2 other courses and the results will be applied in the academic year 2019/2020. One of those courses is Multimedia Learning.

This research is an advanced study conducted in the year 2018 in the form of prototype online learning application for Multimedia Learning courses with Application Architecture as Fig. 1 [11]. In the 2019/2020 academic year, in addition to implementing the previous research results (interactive online learning application module for Multimedia Learning course), in parallel conducted an experiment of implementation effectiveness of students learning results, both reviewed from the 3rd aspect of the online learning mode and also when compared to the mode of face to face learning in class room. The results of this study can also be beneficial as a confirmation/disclaimer/clarification of some of the previous research results of [4],[5],[6],[7],[8].

Through the categorizing approach of online learning of [2], the research aims to investigate the effect of various modes of online learning factors (face-to-face [0\% online], blended [face to face $67 \%$ and $33 \%$ online], web [face to face $33 \%$ and $67 \%$ online], and online [face to face $17 \%$ and $83 \%$ online]) on learning results. In this experiment, all learning materials that will be used by the four learning modes are available online. The subject of this research is the student of ITB STIKOM BALI which in the odd semester 2019/2020 follows a multimedia learning course with the number of classes as many as 4 classes includes 108 students, with each treatment each involving 1 class. The analysis method uses the statistical analysis of ANCOVA (Analysis of Covariance) with one factor and four treatments. From this research is expected to produce recommendations on the implementation of the effective interactive online learning mode.

The detailed description of the purpose of the study is to obtain empirical findings on the following questions:

1) Is there any difference in student learning results of the four modes of online learning by considering the value of discrete mathematics coursework as a precondition?

2) If there are differences, which of these four modes of online learning have equality in their learning results, and which are different?

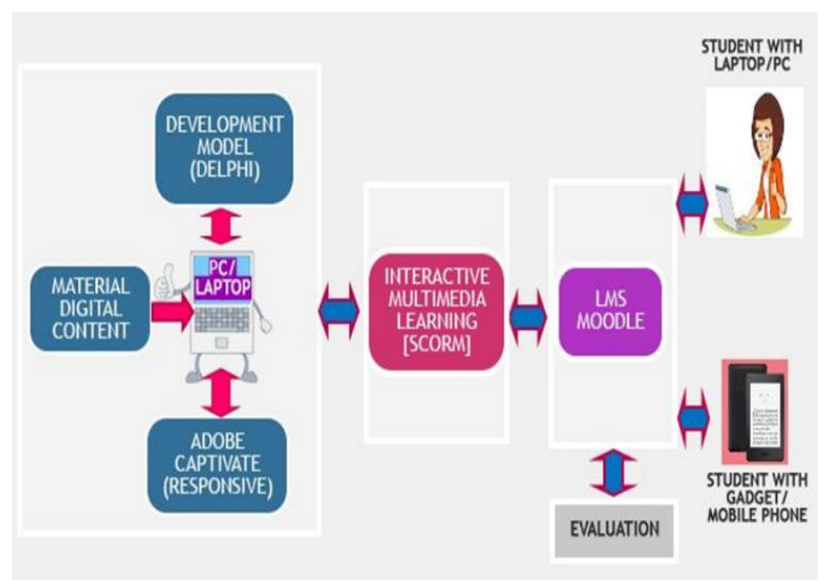

Fig. 1. Application Architecture of Online Learning based on Interactive Multimedia.

\section{METHOD}

\section{A. Research Variable and Experimental Designs}

This research is classified as quantitative research with an experimental approach. The goal is to test the influence of various modes of online learning towards student learning results about its ability to understand the principles of multimedia learning. Various modes of online learning as independent variables with 4 treatments, namely: face-to-face learning ( $0 \%$ online), blended learning ( $33 \%$ online), web (67\% online), and online ( $83 \%$ online) against dependent variable, i.e. student learning result (ability to understand the principles of multimedia learning). The academic value of discrete mathematics students in the previous semester (as a prerequisite course) acts as a covariate variable. The experimental design used a covariance analysis (ANCOVA) with one factor and 4 treatments.

\section{B. Research Subject}

The subject of the research are students of the odd semester of the academic year 2019/2010 of information systems studies program who took the multimedia learning course. The number of students participating in this study is 108 people and divided into 4 classes. From the four classes, 3 classes (web, blended, and online) get a partial online learning treatment from a number of planned meeting schedules, and one other class gets the treatment of face-to-face learning in class room led by a lecturer (for all planned meeting schedules) with the same learning materials available online as the other 3 online classes. The classes are set randomly. Data on the number of fully participating students in the four classes of treatments presented in Table I.

TABLE I. THE NUMBER OF STUDENT OF TREATMENTS OR CLASSES

\begin{tabular}{|l|l|}
\hline Treatments (Modes) (Classes) & $\mathbf{n}$ \\
\hline Online Learning (A) & 33 \\
\hline Web Learning (B) & 29 \\
\hline Blended Learning (C) & 26 \\
\hline Face to Face Learning (D) & 20 \\
\hline \multicolumn{2}{|c|}{ Note: $\mathrm{n}=$ number of students }
\end{tabular}




\section{Treatment Procedure}

This study is conducted for 8 weeks, the experiment schedule for each class of 4 existing classes and the treatment procedure is listed in Table II. Each class of different treatments acquires the same material and is available online via the internet. The difference between class treatments lies in the methods of delivering content (face to face learning, web learning, blended learning, and online learning). The learning process is conducted for 6 weeks from 2 nd meeting to 7 th meeting (with different day schedules for each class).

The first meeting is used to explain to students of each class about things related to the experiment's purpose and schedule, learning methods and measuring learning results. The 8th meeting is used for tests measuring the learning results of each class online, but students are in class. Learning content/modules are presented on the internet and can be accessed every student online via laptop/PC/tablet/smartphone wherever and whenever starting the 2 nd meeting until the 6th meeting. During the 2nd until 6th meeting modules, there is also a quiz or exercise question in the form of multiple choices with questions presented randomly, both a random question and random number the correct choice for each number of questions. Meanwhile, the 7th meeting is used for the enrichment of materials and was done offline (in class) for all classes. Students of each class can complete the quiz scores for each meeting, one day before the learning result measurement test to be conducted. There are data bank questions for each meeting, so that questions presented in each quiz can be different. The appearance of each meeting's learning content for each class differs each day in a week adjusted to the experiment schedule. Some examples of learning content (week-6) are presented in Fig. 2(a), 2(b), 2(c), 2(d) and two samples test of learning results are presented on Fig. 3(a), 3(b). Learning sites can be accessed at https://onlearn.stikom-bali.ac.id/login/ index.php.

\section{Measurement of Research Variable}

There are two different variable. The data obtained, namely, the dependent variables and the variable covariate.

Dependent variables - learning results - data are measured through the test of learning results conducted at the 8th meeting. The test results in the form of multiple choice tests with 25 questions, which are taken randomly from 40 questions in the bank of the questions with the correct answer every question changed position randomly. The test questions covers all the material that is learned, both from the online learning module as well as from multimedia learning books [10] which cover five topics, namely, Innovations in Learning to Multimedia Learning topics (Table II). The desired learning achievement of the test instrument is the ability for students to understand the principles of Multimedia Learning.

Covariate Variables - discrete mathematics value - as one of the prerequisites for the Multimedia Learning course of the previous semester, data are retrieved from the student's final value database of the placed courses.

\section{E. Data Collection and Analysis Method}

The average value of the student's ability to understand the principles of multimedia learning for all treatment classes and also the average value of the discrete mathematics course along with the standard deviation presented in Table III. Data on the results of measurement of two dependent variables and covariates; further are analysed using the statistical analysis ANCOVA (Analysis of covariance) one factor with the help of the SPSS statistical package. However, some important assumptions to match in the ANCOVA analysis, namely: the normality of learning results test data (dependent variables) for the 4th treatment, the variance homogeneity of the 4th treatment, the absence of the data test results of learning that outliers to the 4th treatment, and no interaction between dependent variables (learning result tests) with covariate variables (discrete mathematics value) [12],[13].

TABLE II. PROCEDURE OF TREATMENTS

\begin{tabular}{|c|c|c|c|c|}
\hline \multirow[b]{2}{*}{ Lecture } & \multirow[b]{2}{*}{ Class } & \multirow{2}{*}{$\begin{array}{l}\text { Online } \\
\text { Learning } \\
\text { Mode }\end{array}$} & \multicolumn{2}{|l|}{ Treatments } \\
\hline & & & Delivery Type & $\begin{array}{l}\text { Online Content } \\
\text { Topic }^{*}\end{array}$ \\
\hline Week-1 & A..D & All Modes & \multicolumn{2}{|c|}{$\begin{array}{l}\text { Explanation of experiment, learning } \\
\text { strategy, exercises (quiz), and learning } \\
\text { results test }\end{array}$} \\
\hline \multirow{4}{*}{ Week-2 } & A & Online & Online (off class) & \multirow{4}{*}{$\begin{array}{l}\text { Innovation of } \\
\text { Learning }\end{array}$} \\
\hline & B & Web & Online (off class) & \\
\hline & $\mathrm{C}$ & Blended & Offline (in class) & \\
\hline & $\mathrm{D}$ & Face to Face & Offline (in class) & \\
\hline \multirow{4}{*}{ Week-3 } & $\mathrm{A}$ & Online & Online (off class) & \multirow{4}{*}{$\begin{array}{l}\text { Concepts, } \\
\text { theories and } \\
\text { learning }\end{array}$} \\
\hline & B & Web & Offline (in class) & \\
\hline & $\mathrm{C}$ & Blended & Online (off class) & \\
\hline & $\mathrm{D}$ & Face to Face & Offline (in class) & \\
\hline \multirow{4}{*}{ Week-4 } & A & Online & Online (off class) & \multirow{4}{*}{$\begin{array}{l}\text { Learning style, } \\
\text { pattern, and } \\
\text { evaluation }\end{array}$} \\
\hline & B & Web & Online (off class) & \\
\hline & $\mathrm{C}$ & Blended & Offline (in class) & \\
\hline & $\mathrm{D}$ & Face to Face & Offline (in class) & \\
\hline \multirow{4}{*}{ Week-5 } & A & Online & Online (off class) & \multirow{4}{*}{ E-Learning } \\
\hline & B & Web & Online (off class) & \\
\hline & $\mathrm{C}$ & Blended & Online (off class) & \\
\hline & $\mathrm{D}$ & Face to Face & Offline (in class) & \\
\hline \multirow{4}{*}{ Week-6 } & A & Online & Online (off class) & \multirow{4}{*}{$\begin{array}{l}\text { Multimedia } \\
\text { Learning }\end{array}$} \\
\hline & B & Web & Online (off class) & \\
\hline & $\mathrm{C}$ & Blended & Offline (in class) & \\
\hline & $\mathrm{D}$ & Face to Face & Offline (in class) & \\
\hline Week-7 & A..D & All Modes & Offline (in Class) & Revision \\
\hline Week-8 & A..D & All Modes & Online (in Class) & $\begin{array}{l}\text { Learning Result } \\
\text { Test }\end{array}$ \\
\hline
\end{tabular}

*The content is adapted from the book of Multimedia Pembelajaran: Prinsip Dasar dan Model Pengembangan [10].

TABLE III. AVERAGE SCORE OF DEPENDENT VARIABLE (Y) AND COVARIATE VARIABLE (X)

\begin{tabular}{|l|l|l|l|l|l|}
\hline \multirow{2}{*}{$\begin{array}{l}\text { Learning } \\
\text { Modes or } \\
\text { Treatments } \\
\text { (Class Names) }\end{array}$} & $\mathbf{n}$ & \multicolumn{2}{|l|}{ Learning Results (Y) } & \multicolumn{2}{l|}{$\begin{array}{l}\text { Discrete Mathematics } \\
(\mathbf{X})\end{array}$} \\
\cline { 3 - 6 } & & $\begin{array}{l}\text { Average } \\
\text { score }\end{array}$ & $\begin{array}{l}\text { Standard } \\
\text { deviation }\end{array}$ & $\begin{array}{l}\text { Average } \\
\text { score }\end{array}$ & $\begin{array}{l}\text { Standard } \\
\text { deviation }\end{array}$ \\
\hline Online (A) & 33 & 78.67 & 11.78 & 3.24 & 0.56 \\
\hline Web (B) & 29 & 75.45 & 14.29 & 3.36 & 0.42 \\
\hline Blended (C) & 26 & 78.00 & 12.86 & 3.14 & 0.46 \\
\hline Face to face (D) & 20 & 83.20 & 13.65 & 3.42 & 0.47 \\
\hline
\end{tabular}




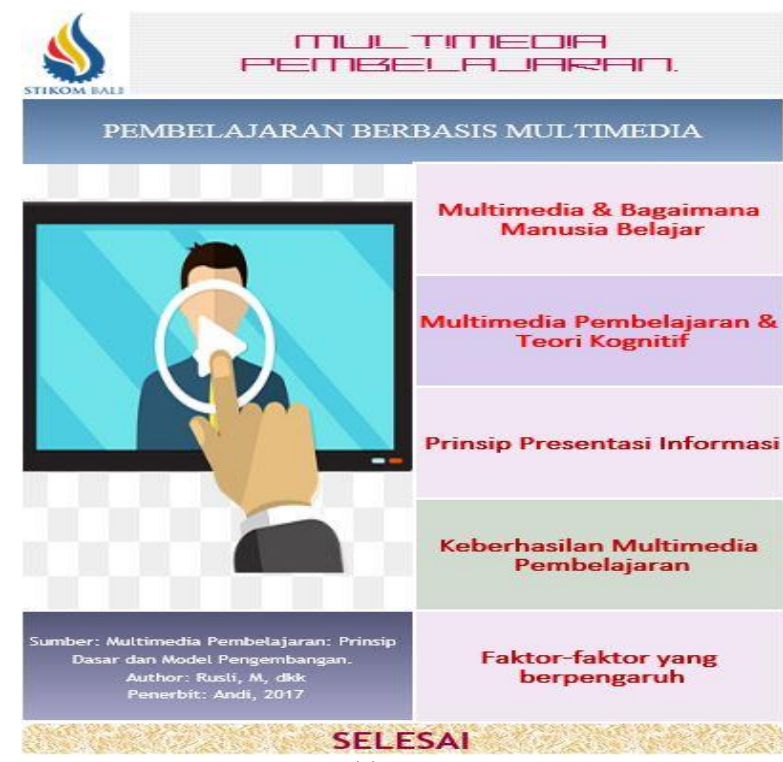

(a)

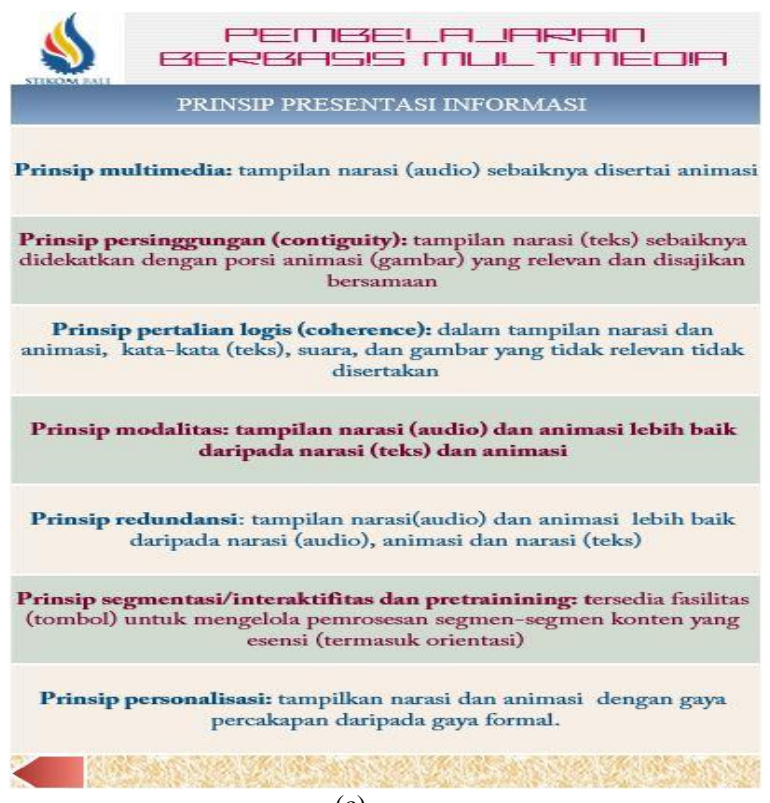

(c)

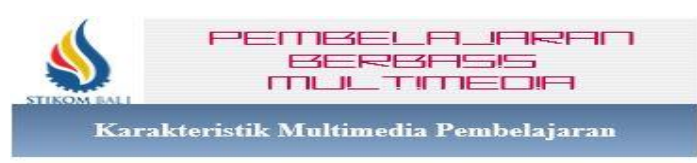

Konten yang dibelajarkan relevan dengan tujuan pembelajaran

Menggunakan metode pembelajaran seperti adanya Menggunakan metode pembelajaran seperti adanya
contoh dan latihan/praktek guna membantu pembelajar
belajar

Menggunakan elemen-elemen media seperti kata-kata (teks) dan gambar-gambar dalam menyampaikan konten dan metode pembelajaran Dirancang untuk pebelajar agar mampu belajar mandiri Membangun pengetahuan dan kecakapan (skill) baru
yang berhubungan dengan tujuan belajar atau meningkatkan kinerja organisasi
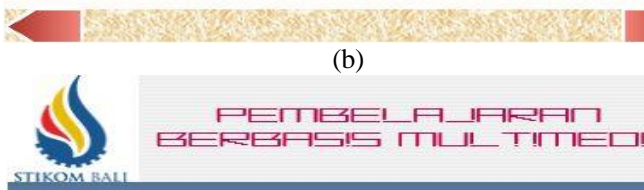

(b)

FAKTOR-FAKTOR YANG MEMPENGARUHI KEEFEKTIFAN

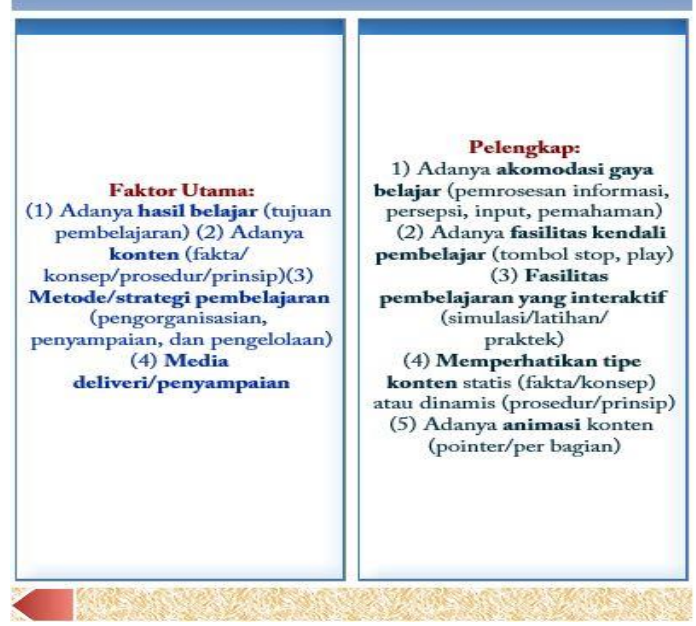

(d)

Fig. 2. (a) Multimedia Computer based Learning Menu. (b) Content Description of the 2nd Sub-Menu. (c) Content Description of the 3rd Sub-Menu. (d) Content Description of the 5th Sub-Menu.

Tipe berpikir logis dan kritis serta digunakan ketika kita perlu mempersempit keputusan-keputusan yang akan diambil dari alternatif-alternatif yang ada disebut

\section{Select one:}

a. Kreatif

b. Inovatif

c. Konservatif

d. Kritis
Manfaat multimedia dalam pendidikan bagi pebelajar adalah sebagai berikut, kecuali:
Select one:
a. Menghemat waktu dengan topik yang lebih menantang
b. Dapat belajar dengan tutor yang sabar (multimedia sebagai tutor)
c. Dapat meningkatkan aspek motivasi dalam belajar secara mandiri/kolaboratif
d. Dapat belajar secara aktif dan menerima feedback

(b)

Fig. 3. Test Question of Logical and Critical thinking. (b) Test Questions of Multimedia Learning Benefits. 


\section{FINDINGS}

\section{A. Testing Assumption in ANCOVA}

The results of the tests on the assumption of normality to the data of learning results for the 4th treatment with the Shapiro-Wilks test, indicating that the assumption of normality has been fulfilled for each treatment with significance values $(\mathrm{A}=0.186 ; \mathrm{B}=0.459 ; \mathrm{C}=0.091 ; \mathrm{D}=$ 0.129 ) which is greater than $\alpha=0.05$ (Table IV). The result of Levene's tests for the homogeneity of variance over the data of learning results obtained a significance value of 0.282 greater than $\alpha=0.05$. Thus assuming the homogeneity of variance is fulfilled (Table V). Meanwhile, based on chart of Box Plot of learning result data, the 4th treatment shows no outliers (Fig. 4). Furthermore, the test results of the absence of interactions between dependent with covariate variables are shown through the results of covariance analysis on the interaction factor (TYPE * MATDIS) with a significance value of 0.382 greater than $\alpha=0.05$ (Table VI).

With the fulfilment of the test results about the 4th assumption, the covariance analysis can be continued to confirm the presence or absence of the effect of online learning modes factor for the 4 th treatment on learning results by considering factor of discrete mathematics value of students in the previous semester. Analysis results are presented in Table VII.

TABLE IV. Normality Test OF DePEndent VARIAble (Y)

\begin{tabular}{|c|c|c|c|}
\hline \multirow{2}{*}{$\begin{array}{l}\text { Type of } \\
\text { Treatments }\end{array}$} & \multicolumn{3}{|c|}{ Shapiro-Wilk } \\
\hline & Statistic & df & Sig. \\
\hline A & 0.955 & 33 & $0.186^{\mathrm{ns}}$ \\
\hline B & 0.959 & 29 & $0.314^{\mathrm{ns}}$ \\
\hline $\mathrm{C}$ & 0.933 & 26 & $0.091^{\mathrm{ns}}$ \\
\hline $\mathrm{D}$ & 0.926 & 20 & $0.129^{\mathrm{ns}}$ \\
\hline
\end{tabular}

TABLE V. LEVENE'S TEST OF EQUALITY OF ERROR VARIANCES OF DEPENDENT VARIABLE(Y)

\begin{tabular}{|l|l|l|l|}
\hline F & df1 & df2 & Sig. \\
\hline 1.012 & 3 & 104 & $0.391^{\text {ns }}$ \\
\hline \multicolumn{4}{|c|}{ Note: ns = Not Significant; $\alpha=0.05$}
\end{tabular}

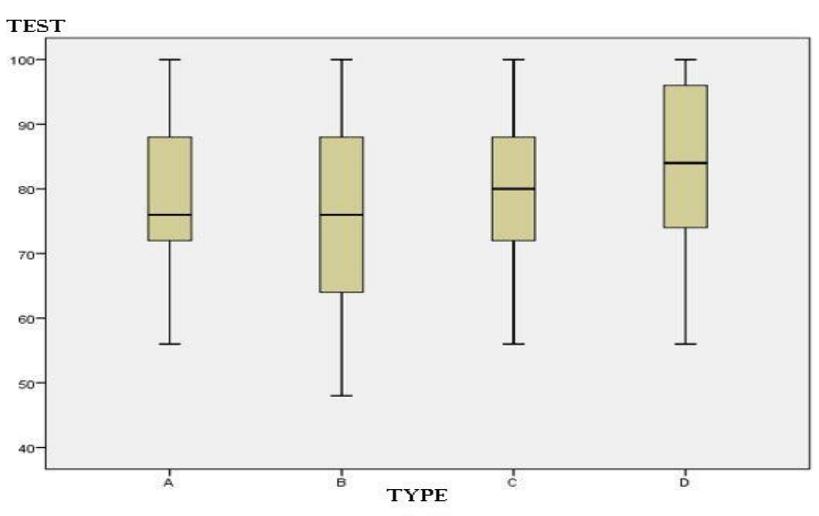

Fig. 4. Box Plot Diagram of Online Learning Mode (A, B, C, D).
TABLE VI. ANALYSIS OF COVARIANCE OF MAIN EFFECTS AND INTERACTION

\begin{tabular}{|c|c|c|c|c|c|}
\hline Source & $\begin{array}{l}\text { Type III Sum } \\
\text { of Squares }\end{array}$ & df & $\begin{array}{l}\text { Mean } \\
\text { Square }\end{array}$ & $\mathbf{F}$ & Sig. \\
\hline $\begin{array}{l}\text { Corrected } \\
\text { Model }\end{array}$ & $1857.017^{\mathrm{a}}$ & 7 & 265.288 & 1.589 & 0.147 \\
\hline Intercept & 7603.657 & 1 & 7603.657 & 45.547 & 0.000 \\
\hline TYPE & 422.639 & 3 & 140.880 & 0.844 & $0.473^{\mathrm{ns}}$ \\
\hline MATDIS (X) & 553.188 & 1 & 553.188 & 3.314 & $0.072^{\mathrm{ns}}$ \\
\hline $\begin{array}{l}\text { TYPE * } \\
\text { MATDIS (X) }\end{array}$ & 565.181 & 3 & 188.394 & 1.129 & $0.341^{\mathrm{ns}}$ \\
\hline Error & 16693.946 & 100 & 166.939 & & \\
\hline Total & 683760.000 & 108 & & & \\
\hline $\begin{array}{l}\text { Corrected } \\
\text { Total }\end{array}$ & 18550.963 & 107 & & & \\
\hline \multicolumn{6}{|c|}{ Dependent Variable: Test } \\
\hline \multicolumn{6}{|c|}{ R Squared $=0.100$ (Adjusted R Squared $=0.037$ ) } \\
\hline \multicolumn{6}{|c|}{ Notes: TYPE $=$ The Type of Treatments (A, B, C, D) } \\
\hline \multicolumn{6}{|c|}{$\operatorname{MATDIS}(\mathrm{X})=$ Discrete Mathematics as Covariate Variable } \\
\hline & ГYPE * MATDIS (X) & Interacti & f Treatments $T$ & and Discre & Mathematics \\
\hline
\end{tabular}

TABLE VII. ANALYSIS OF COVARIANCE OF MAIN EFFECTS

\begin{tabular}{|l|l|l|l|l|l|}
\hline Source & $\begin{array}{l}\text { Type III Sum } \\
\text { of Squares }\end{array}$ & df & $\begin{array}{l}\text { Mean } \\
\text { Square }\end{array}$ & F & Sig. \\
\hline $\begin{array}{l}\text { Corrected } \\
\text { Model }\end{array}$ & $1291.836 \mathrm{a}$ & 4 & 322.959 & 1.927 & 0.111 \\
\hline Intercept & 8732.145 & 1 & 8732.145 & 52.112 & 0.000 \\
\hline TYPE & 669.466 & 3 & 223.155 & 1.332 & $0.268 \mathrm{~ns}$ \\
\hline MATDIS & 572.579 & 1 & 572.579 & 3.417 & $0.067 \mathrm{~ns}$ \\
\hline Error & 17259.127 & 103 & 167.564 & & \\
\hline Total & 683760.000 & 108 & & & \\
\hline $\begin{array}{l}\text { Corrected } \\
\text { Total }\end{array}$ & 18550.963 & 107 & & & \\
\hline \multicolumn{5}{|c|}{$\begin{array}{c}\text { R Squared = 0.070 (Adjusted R Squared }=0.034) \\
\text { Notes: TYPE = The Type of Treatments (A, B, C, D) }\end{array}$} \\
\hline
\end{tabular}

\section{B. Analysis of the Results}

Based on the results of the analysis of covariance in Table VI, it can be concluded that there is no real influence of interaction between dependent variables (student learning results) and Covariate variables (the value of discrete mathematics courses). Therefore, the covariance analysis can be resumed without including the interaction variables between the dependent variable and the covariate variable (Table VII).

Based on the results of analysis of covariance in Table VII, it can be concluded that there is no real influence different treatment from the 4 modes of online learning (online, web, blended, and face to face) by considering the value of discrete mathematics towards student learning results.

\section{Discussion}

Having observed the results of covariance analysis in Table VII, it is concluded that there is no real influence of the treatment of the 4 modes of online learning (online, web, blended, and face to face) of student learning results. Thus it 
can be said that online learning for 4 kinds of treatments or modes of online learning (face to face, blended, web, online) gives the student learning results equality to the student's ability to understand the principles of multimedia learning, by considering the value of discrete mathematics in the previous semester. It is in line with the research results of [5],[6],[8]. These conditions can occur due to some of the following:

a) The student-participants of this course include senior students (already in the 5th or 7th semester). Each student is able to study independently. All students can learn by using a computer or a mobile phone, and also learn deeply through the content, study by reading books, and they have ability in time management as well.

b) The content of the learning is interactive multimedia and is available online (internet) via Moodle (as Learning Management Systems/LMS) for four kinds of treatments, so there are equal opportunities for the four student groups to be able to access to the learning materials repeatedly and deeply in the process of learning anytime and anywhere along the schedule that has been set.

\section{CONCLUSION AND SugGeStion}

\section{A. Conclusion}

Online learning is the more effective and suitable method that can encourage students to conduct their learning process individually or collectively by using the provided interactivemultimedia teaching materials. The prove of the concluding statement is on which the result of the experimental-classes showing the significant value; there is equal ability to understand the principles of multimedia learning by considering the value of discrete mathematics i.e. online mode ( $83 \%$ online, and $17 \%$ face-to-face), web mode (67\% online, and $33 \%$ face-to-face), blended mode (33\% online, and $67 \%$ face-to-face), and face to face mode ( $0 \%$ online).

\section{B. Suggestion}

It is recommended to the development of online learning for conceptual type teaching materials or student learning outcomes at the level of understanding. Futher research is necessary to obtain more details about the higher learning content type or higher level of learning achievement.

\section{ACKNOWLEDGMENT}

Author would like to gratitude the management of the Institut Teknologi dan Bisnis STIKOM BALI for the supports and funds provided for the 2019 Internal Research.

\section{REFERENCES}

[1] FAO, "E-learning Methodologies: A guide for designing and developing e-learning courses", Rome: Food and Agriculture Organization off the United Nations, 2011.

[2] I.E. Allen and J. Seaman, "Changing course: Ten years of online education in the United States", Babson Park MA: Babson Survey Research Group and Quahog Research Group, LLC, 2013.

[3] C.B. Aslanian and D.L. Clinefelter, "Online college students 2013: Comprehensive data on demands and preferences", Louisville, KY: The Learning House, Inc., 2013.

[4] L. MacKenzie and K. Ballard, "Can Using Individual Online Interactive Activities Enhance Exam Results?", MERLOT Journal of Online Learning and Teaching. 11(2), 2015, 262-266.

[5] A.L. Porter, M.E. Pitterle, and M.S. Hayney, "Comparison of Online Versus Classroom Delivery of an Immunization Elective Course", American Journal of Pharmaceutical Education, 78(5), 2014, 96.

[6] T. Nguyen, "The Effectiveness of Online Learning: Beyond No Significant Difference and Future Horizons", MERLOT Journal of Online Learning and Teaching, 11(2), 2015.

[7] F. Harahap, N.E.A Nasution, and B. Manurung, "The Effect of Blended Learning on Student's Learning Achievement and Science Process Skills in Plant Tissue Culture Course", International Journal of Instruction, 12(1), 2019.

[8] I.Y. Kazu and M. Demirkol, "Effect Of Blended Learning Environment Model On High School Students' Academic Achievement",The Turkish Online Journal of Educational Technology, 13(1), 2014.

[9] R.C. Clark and R.E. Mayer, "eLearning and the Science of Instruction: Proven Guidelines for Consumers and Designers of Multimedia Learning”, Fourth Edition. San Francisco: In Print of Wiley, 2016.

[10] M. Rusli, D. Hermawan, and N.N. Supuwiningsih, "Multimedia Pembelajaran yang Inovatif: Prinsip Dasar dan Model Pengembangan", Yogyakarta: Andi, 2017.

[11] M. Rusli, "The Framework of Development Online Learning based on Interactive Multimedia Learning in STIKOM Bali", International Journal of Computer Applications. 181(27), 2018, 37-42.

[12] J.F. Hair, W.C. Black, B.J. Babin, and R.E. Anderson, "Multivariate Data Analysis", Seventh Edition. Upper Saddle River, New Jersey: Pearson Education, Inc., 2014.

[13] H.J. Seltman, "Experimental Design and Analysis", 2018. Retrieved January 12, 2020 from http://www.stat.cmu.edu/_hseltman/309/Book /Book.pdf. 